\title{
Investigation of Reading and Writing Strategies Used by Future Teachers: Do Good Readers Write Well?
}

Ersoy Topuzkanamış*

Necatibey Faculty of Education, Balıkesir University Soma Street, Altteylül, Balıkesir, Turkey

Corresponding Author: Ersoy Topuzkanamış, E-mail: ersoytopuzkanamis@gmail.com

\section{ARTICLE INFO}

Article history

Received: February 12, 2019

Accepted: May 12, 2019

Published: June 30, 2019

Volume: 10 Issue: 3

Advance access: May 2019

Conflicts of interest: None

Funding: None

\author{
Key words: \\ Reading Strategies, \\ Writing Strategies, \\ Candidate Teachers, \\ Turkish Language Education, \\ Teacher Training
}

\begin{abstract}
The number of studies regarding determining reading and writing strategies that students use and the effect of strategy training on skills development is quite abundant. However, no study has ever investigated whether there is a correlation between reading and writing strategies in terms of frequency of use. In spite of this, there have been several resources indicating that reading and writing skills are interrelated. Based on the assumption that this indication might possibly impact the use of strategies to some extent, current research aimed to determine the types of strategies used by first grade undergraduate students at a faculty of education together with their frequency of use and if there is a correlation between two scores. To conduct the research, 420 first-grade participants from various departments of Necatibey Faculty of Education, Ballkesir University were selected. As for the data collection, these students were administered a Reading Strategies Survey (RSS) developed by Karatay (2007) and a Writing Strategies Survey (WSS) developed by Ülper (2011). Related statistical analyses were conducted based on the data gathered from the scale, revealing that females used reading and writing strategies more often than males, and there was a moderate and positive correlation between the frequencies of the uses of writing and reading strategies. Apart from that, no difference was detected in terms of departments.
\end{abstract}

\section{INTRODUCTION}

The number of texts to read has been constantly increasing in recent years. In addition, opportunities to produce written texts have been thriving in humankind's favor. Not far from 10 years ago, people were only concerned with reading some basic or complex texts such as money, bills, signs, bus numbers, fliers, ads, newspapers or magazines, books, articles, court verdicts, etc. and spent relatively small amounts of time to write letters, short notes, and application forms; today, they frequently read and write many good or bad texts on social network environments such as Facebook, Twitter, Instagram, etc. (Hinduja \& Patchin, 2007; Vural \& Bat, 2010; Kaplan \& Haenlein, 2010; O'Keeffe \& Clarke-Pearson, 2011; Solmaz, Tekin, Herzem \& Demir, 2013). Reading and writing which are regarded as learning tools in educational context has evolved to be the constant part of daily life thanks to technology. This, without a doubt, is not a bad situation. However, when both skills that are the part of communication process lack quality and certain standards, it brings forth numerous communication problems. It is possible to observe these instances on social media environments on a daily basis. Thusly, it is acknowledged that students are not on the anticipated levels regarding their reading and writing competencies. For instance, the rate of students successful in reading and writing are considerably low in the USA (NAEP, 2009; NAEP, 2011). In addition, a similar case can be observed in Turkey in the sense of PISA results (MNE, 2015).

Nowadays it can be witnessed that information has been flowing and remarkably diversifying in alignment with various developments and advancements in technological, cultural, and social domains. The diversity and increase in information throughout the time have brought about problems resulting with difficulties in classifying the information. As communication tools and information sources swell in number, leading to easy access to information, it is consequentially accompanied by a pollution of information (Kumar, 2013; Firat \& Kurt, 2015; Özdemir, 2016).

As well as difficulties with classifying it, accurate comprehension of the information can be regarded as a communication problem. It is crucial for people in the position of receiver to comprehend messages accurately since the most common and practical tool for communication is language. On the other hand, on today's terms, it is required and expected from individuals to not only comprehend the information but also put it into a structure, in other words, reconstruct the information. At this point, it is underlined 
that written texts need to be constructed accurately, nicely, and efficiently. It is not possible to maintain a healthy communication with texts that might be considered incorrect, incomplete, subjective, etc.

From past to present, reading and writing have been tools used by people for communication purposes. However, in time, they have transformed into tools of learning to be used in educational contexts not only for communication but also for teaching thinking and learning skills (National Research Council, 1998). Therefore, reading and writing activities performed in educational environments have gained the attribution of educating the brain in terms of exploring the relationships and connections between thoughts and concepts. Based on this insight, it is plausible to turn in the direction of training strategic readers and writers on every level ranging from primary to higher education (Graham, Harris, Kiuhara \& Fishman, 2017). For this reason, the matter of to what extent pre-service teachers use reading and writing strategies appears important to address. Although reading and writing activities are regarded as a job for Turkish or literature teachers, in essence, they are simply areas in which everyone who communicates, thusly teachers from all departments, should be proficient; in that, to increase the chance for students to acquire high levels of comprehension and narration (?), teachers must reach these levels first. Considering that with the escalating influence of technology in educational environments, teachers get more opportunities to establish a written communication with students, communication proficiency gains even more vitality.

In the light of the literature, it was suggested that reading strategies develop reading skill while writing strategies are important to flourish writing skills (Casbarro, 1996; Burles, 2000; Yazar, 2001; De La Paz \& Graham, 2002; Hpkins, 2002; Gelen, 2003; Şen, 2003; İnal, 2006; Monroe \& Troia, 2006; Karatay, 2007; Ülper, 2008; Topuzkana$\mathrm{m} 1$ ş, 2009). Aside from that, it was stated that writing strategies improve reading comprehension (Zsigmond, 2015); in addition, teaching reading strategies is the fundamental way of improving reading comprehension (Brand-Gruwel, Aarnoutse \& van den Bos, 1998; Cain, 1999; Spörer, Brunstein \& Kieschke, 2009; Muijselaar \& de Jong, 2015). In this context, this is an indication that reading and writing skills complement and support each other as acknowledged over time. As depicted by many researchers, reading and writing interact with one another. People with improved reading skill write better than those with unimproved skills whereas people with well-developed writing skills read more compared to those with low-level writing skills. Apart from this, it is acknowledged that individuals attempt to produce meaning, using their knowledge and experiences in the process of both reading and writing (Tierney \& Pearson, 1983; Shen, 2009). Besides being driven to use more cognitive strategies in terms of frequency and amount, in circumstances during which two skills are used together, students' critical thinking skills are improved (Tierney, Soter, O'Flahavan \& McGinley, 1984). After all, gaining experience through reading so as to produce a good writing is a widely accepted phenomenon (Clouse, 2002).

It is thought that to investigate the frequency of strategy use during reading and writing and to determine if there is a correlation between them will contribute to our understanding of the nature of reading and writing as well as to the literature.

\section{PURPOSE}

The research investigated to what extent pre-service teachers use reading and writing strategies and whether there is a correlation between two frequency values. To serve the purpose, sub-problems presented below will be answered:

1. What are states of pre-service teachers' use of strategies prior to, during, and after reading?

2. What are the states of pre-service teachers' use of strategies prior to, during, and after writing?

3. Is there any difference between pre-service teachers' use of strategies prior to, during, and after reading and their overall use of reading strategies in terms of genders?

4. Is there any difference between pre-service teachers' use of strategies prior to, during, and after writing and their overall use of writing strategies in terms of genders?

5. Does pre-service teachers' frequency of use in reading strategies differ in terms of department?

6. Does pre-service teachers' frequency of use in writing strategies differ in terms of department?

7. Is there a correlation between pre-service teachers' frequency of use regarding reading and writing strategies?

\section{METHOD}

\section{Participants}

The research involved first grade students studying at Necatibey Faculty of Education, Balıkesir University during the Fall semester of 2017-2018 academic year as participants. Distribution of participants according to gender and departments is presented in Table 1 .

Among the participants, there were 299 (71.19\%) female and $121(28.80 \%)$ male students while in terms of department, 52 Turkish Language, 89 Pre-school, 11 Computer Education, 58 Primary Education, 32 Social Sciences, 50 Math, 20 Turkish Language and Literature, 57 Guidance and Counselling, 8 Physics, 19 Biology, and 24 Music Education to make up a total of 420 students volunteered to participate.

\section{Data Collection Tools and Procedure}

To obtain data, the Reading Strategies Scale (RSS) developed by Karatay (2007) and the Writing Strategies Scale (WSS) developed by Ülper (2011) were used. Karatay calculated reliability coefficient for the 33-item RSS as.84 while Ülper revealed the coefficient for 21-item WSS as.87. Values of reliability coefficients indicate that both scales are reliable (Şencan, 2005). Each item in both scales includes response options as follows: "Always", "Often", "Sometimes", "Rarely", and "Never". 
Table 1. Distribution of participants in terms of gender and departments

\begin{tabular}{|c|c|c|c|c|}
\hline \multirow[t]{2}{*}{ Department } & & \multicolumn{2}{|c|}{ Gender } & \multirow[t]{2}{*}{ Total } \\
\hline & & Female & Male & \\
\hline \multirow[t]{2}{*}{ Turkish Language } & Count & 38 & 14 & 52 \\
\hline & $\%$ & $12,7 \%$ & $11,6 \%$ & $12,4 \%$ \\
\hline \multirow{2}{*}{$\begin{array}{l}\text { Pre-School } \\
\text { Education }\end{array}$} & Count & 66 & 23 & 89 \\
\hline & $\%$ & $22,1 \%$ & $19,0 \%$ & $21,2 \%$ \\
\hline \multirow{2}{*}{$\begin{array}{l}\text { Computer Education } \\
\text { and Teaching } \\
\text { Technologies }\end{array}$} & Count & 7 & 4 & 11 \\
\hline & $\%$ & $2,3 \%$ & $3,3 \%$ & $2,6 \%$ \\
\hline \multirow[t]{2}{*}{ Primary Education } & Count & 47 & 11 & 58 \\
\hline & $\%$ & $15,7 \%$ & $9,1 \%$ & $13,8 \%$ \\
\hline \multirow[t]{2}{*}{ Social Sciences } & Count & 21 & 11 & 32 \\
\hline & $\%$ & $7,0 \%$ & $9,1 \%$ & $7,6 \%$ \\
\hline \multirow[t]{2}{*}{ Mathematics } & Count & 42 & 8 & 50 \\
\hline & $\%$ & $14,0 \%$ & $6,6 \%$ & $11,9 \%$ \\
\hline \multirow{2}{*}{$\begin{array}{l}\text { Turkish Language } \\
\text { and Literature }\end{array}$} & Count & 12 & 8 & 20 \\
\hline & $\%$ & $4,0 \%$ & $6,6 \%$ & $4,8 \%$ \\
\hline \multirow{2}{*}{$\begin{array}{l}\text { Guidance and } \\
\text { Counselling }\end{array}$} & Count & 37 & 20 & 57 \\
\hline & $\%$ & $12,4 \%$ & $16,5 \%$ & $13,6 \%$ \\
\hline \multirow[t]{2}{*}{ Physics } & Count & 4 & 4 & 8 \\
\hline & $\%$ & $1,3 \%$ & $3,3 \%$ & $1,9 \%$ \\
\hline \multirow[t]{2}{*}{ Biology } & Count & 15 & 4 & 19 \\
\hline & $\%$ & $5,0 \%$ & $3,3 \%$ & $4,5 \%$ \\
\hline \multirow[t]{2}{*}{ Music } & Count & 10 & 14 & 24 \\
\hline & $\%$ & $3,3 \%$ & $11,6 \%$ & $5,7 \%$ \\
\hline \multirow[t]{2}{*}{ Total } & Count & 299 & 121 & 420 \\
\hline & $\%$ & $71,19 \%$ & $28,80 \%$ & $100 \%$ \\
\hline
\end{tabular}

The data collection for the research took place during the second and the third weeks of the Fall semester. Regarding the setting for data collection, Turkish Language 1: Written Expression class that students from all departments take was chosen and the lecturer in charge of the class was asked for permission to conduct research. Following the appointment with lecturer, participants were informed about the study and asked to leave no item unanswered by emphasizing that their personal information would be kept hidden. When an unanswered item was detected, participants were encouraged to answer it.

In data analysis, one-way Anova and t-tests were run for the data sets indicating normal distribution, and Pearson Correlation coefficient was calculated.

\section{FINDINGS AND INTERPRETATION}

Descriptive statistics regarding pre-service teachers' states of strategy use prior to, during, and after reading are presented below:

Considering the Table 2, it was indicated that the most frequently used strategies were reading for a purpose (1) and scanning the text (5) whereas the least favored strategies were note taking (2) and paraphrasing (8). In relation, it can be inferred that students pay attention to gaining information about the text in accordance with their purposes during reading activities; however, they neglect strategies with the aim to remember. Frequent use of setting a purpose and seeking prior knowledge undoubtedly increases the possibility of a high-level reading comprehension. Additionally, the rare use of note taking and paraphrasing strategies can be interpreted with two perspectives. First, students either do not read loaded texts requiring note-taking and paraphrasing by avoiding them or even if they read

Table 2. Descriptive statistics regarding the strategies prior to reading

\begin{tabular}{|c|c|c|c|c|c|c|c|c|c|c|}
\hline \multirow[t]{2}{*}{ Strategy } & \multicolumn{2}{|c|}{ Never } & \multicolumn{2}{|c|}{ Rarely } & \multicolumn{2}{|c|}{ Sometimes } & \multicolumn{2}{|c|}{ Often } & \multicolumn{2}{|c|}{ Always } \\
\hline & $\mathbf{F}$ & $\%$ & $\mathbf{F}$ & $\%$ & $\mathbf{F}$ & $\%$ & $\mathbf{F}$ & $\%$ & $\mathbf{F}$ & $\%$ \\
\hline 1. I read for a purpose. & 8 & 1,9 & 22 & 5,2 & 76 & 18,1 & 194 & 46,2 & 120 & 28,6 \\
\hline $\begin{array}{l}\text { 2. I take notes while reading to } \\
\text { increase comprehension. }\end{array}$ & 47 & 11,2 & 104 & 24,8 & 137 & 32,6 & 88 & 21 & 44 & 10,5 \\
\hline $\begin{array}{l}\text { 3. I use prior knowledge to increase } \\
\text { comprehension. }\end{array}$ & 12 & 2,9 & 46 & 11 & 90 & 21,4 & 167 & 39,8 & 105 & 25 \\
\hline $\begin{array}{l}\text { 4. When the text is hard, if necessary, } \\
\text { I read aloud to comprehend it. }\end{array}$ & 27 & 6,4 & 38 & 9 & 72 & 17,1 & 139 & 33,1 & 144 & 34,3 \\
\hline $\begin{array}{l}\text { 5. Prior to reading, I scan the text to } \\
\text { see what it is about. }\end{array}$ & 7 & 1,7 & 26 & 6,2 & 57 & 13,6 & 162 & 38,6 & 168 & 40 \\
\hline $\begin{array}{l}\text { 6. I read the text slowly but carefully } \\
\text { to make sure I comprehend it. }\end{array}$ & 11 & 2,6 & 24 & 5,7 & 84 & 20 & 175 & 41,7 & 126 & 30 \\
\hline $\begin{array}{l}\text { 7. I question whether the content of } \\
\text { the text is suitable for my purpose. }\end{array}$ & 10 & 2,4 & 39 & 9,3 & 111 & 26,4 & 161 & 38,3 & 99 & 23,6 \\
\hline $\begin{array}{l}\text { 8. I paraphrase important information } \\
\text { in the text. }\end{array}$ & 23 & 5,5 & 62 & 14,8 & 122 & 29 & 142 & 33,8 & 71 & 16,9 \\
\hline $\begin{array}{l}\text { 9. I look for the writer's name (if } \\
\text { provided) prior to reading. }\end{array}$ & 13 & 3,1 & 45 & 10,7 & 86 & 20,5 & 116 & 27,6 & 160 & 38,1 \\
\hline
\end{tabular}


such texts, they do not consider them to be worth remembering. This occurrence could be a product of tests including mainly multiple-choice questions or students deeming what they read unworthy of commentating. Since probability of chance success in multiple choice tests are higher than open-ended questions, students can find the correct answer by making associations between the question and choices even if they lack the knowledge required to answer it, therefore making the knowledge related to the question obsolete. Furthermore, the introduction and advancements in several digital applications enabling students to store knowledge similarly drive the minds to not remembering. Based on the explorations in the research, strategies exploited by students such as using prior knowledge (3), reading aloud (4), and reading slowly (6) are techniques to which students turn with the aim to remember knowledge when preparing for exams.

When the Table 3 is examined, it can be noticed that the most frequently used strategies were re-reading when focus is lost (11), benefitting from visuals (17), and concentrating on hard parts (16) whereas the least used strategies were using dictionaries (15), schematizing (21), and set- ting a focal point (14). Regarding the highly favored strategies, it can be deduced that students frequently face attention deficiencies and they often come across hard parts in the texts they read. Considering the least favored strategies, on the other hand, in spite of being urged by teachers to use them, students do not like using dictionaries, prefer schematizing, care about where they should focus on when reading a text. Apart from that, it is observed that students do not feel inclined to consider rephrasing (22), context-related cues (19), and forming meanings outside the text. According to the insight provided by the table, out of 14 strategies, seven of them were used by half of the students either very rarely or never. To sum, it can be claimed that students were not proficient enough to make intertextual and non-textual meanings, experiencing problems.

Regarding the Table 4 presented, the most frequent strategies used by students were adjusting the pace of reading (32), rereading (27), comparing (25), and guessing (26) while the least frequent strategies were rephrasing (31), asking questions (28), and sharing (33). It is noteworthy that high frequency in adjusting the pace of

Table 3. Descriptive statistics regarding the strategies during reading

\begin{tabular}{|c|c|c|c|c|c|c|c|c|c|c|}
\hline \multirow[t]{2}{*}{ Strategy } & \multicolumn{2}{|c|}{ Never } & \multicolumn{2}{|c|}{ Rarely } & \multicolumn{2}{|c|}{ Sometimes } & \multicolumn{2}{|c|}{ Often } & \multicolumn{2}{|c|}{ Always } \\
\hline & $\mathbf{F}$ & $\%$ & $\mathbf{F}$ & $\%$ & $\mathbf{F}$ & $\%$ & $\mathbf{F}$ & $\%$ & $\mathbf{F}$ & $\%$ \\
\hline $\begin{array}{l}\text { 10. Prior to reading I scan the text in terms } \\
\text { of characteristics such as the length, } \\
\text { structures, etc. }\end{array}$ & 13 & 3,1 & 36 & 8,6 & 101 & 24 & 152 & 36,2 & 118 & 28,1 \\
\hline $\begin{array}{l}\text { 11. I try to return to the part I have read when } \\
\text { I lose focus. }\end{array}$ & 8 & 1,9 & 10 & 2,4 & 45 & 10,7 & 149 & 35,5 & 208 & 49,5 \\
\hline $\begin{array}{l}\text { 12. I underline or circle the information in the } \\
\text { text to remember it. }\end{array}$ & 31 & 7,4 & 49 & 11,7 & 92 & 21,9 & 134 & 31,9 & 114 & 27,1 \\
\hline $\begin{array}{l}\text { 13. I check the information and ideas in the text } \\
\text { in terms of their practicality in daily life. }\end{array}$ & 15 & 3,6 & 71 & 16,9 & 135 & 32,1 & 141 & 33,6 & 58 & 13,8 \\
\hline $\begin{array}{l}\text { 14. I decide what points to focus on prior to } \\
\text { reading. }\end{array}$ & 32 & 7,6 & 98 & 23,3 & 146 & 34,8 & 109 & 26 & 35 & 8,3 \\
\hline $\begin{array}{l}\text { 15. I use sources of reference like dictionaries } \\
\text { to increase reading comprehension. }\end{array}$ & 54 & 12,9 & 125 & 29,8 & 114 & 27,1 & 94 & 22,4 & 33 & 7,9 \\
\hline $\begin{array}{l}\text { 16. When the text seems hard, I concentrate } \\
\text { to comprehend what I read. }\end{array}$ & 4 & 1 & 22 & 5,2 & 75 & 17,9 & 177 & 42,1 & 142 & 33,8 \\
\hline $\begin{array}{l}\text { 17. I benefit from visuals like diagrams, } \\
\text { pictures, and tables in the text to } \\
\text { comprehend what I read. }\end{array}$ & 15 & 3,6 & 43 & 10,2 & 73 & 17,4 & 144 & 34,3 & 145 & 34,5 \\
\hline $\begin{array}{l}\text { 18. I occasionally stop to reflect on what I } \\
\text { have just read. }\end{array}$ & 14 & 3,3 & 54 & 12,9 & 120 & 28,6 & 151 & 36 & 81 & 19,3 \\
\hline $\begin{array}{l}\text { 19. I use clues regarding the } \\
\text { context (contextual clues) to comprehend } \\
\text { what I read better. }\end{array}$ & 22 & 5,2 & 74 & 17,6 & 139 & 33,1 & 133 & 31,7 & 52 & 12,4 \\
\hline $\begin{array}{l}\text { 20. I paraphrase thoughts in the text to } \\
\text { comprehend it better. }\end{array}$ & 18 & 4,3 & 54 & 12,9 & 133 & 31,7 & 138 & 32,9 & 77 & 18,3 \\
\hline $\begin{array}{l}\text { 21. I schematize, illustrate, or visualize the } \\
\text { information to remember what I read. }\end{array}$ & 83 & 19,8 & 111 & 26,4 & 96 & 22,9 & 79 & 18,8 & 51 & 12,1 \\
\hline $\begin{array}{l}\text { 22. I pay attention to punctuations, bold or italic } \\
\text { items to identify key information in the text. }\end{array}$ & 34 & 8,1 & 71 & 16,9 & 104 & 24,8 & 134 & 31,9 & 77 & 18,3 \\
\hline $\begin{array}{l}\text { 23. I critically analyze and evaluate the } \\
\text { information presented in the text. }\end{array}$ & 13 & 3,1 & 56 & 13,3 & 127 & 30,2 & 152 & 36,2 & 72 & 17,1 \\
\hline
\end{tabular}


Table 4. Descriptive statistics regarding the strategies after reading

\begin{tabular}{|c|c|c|c|c|c|c|c|c|c|c|}
\hline \multirow[t]{2}{*}{ Strategy } & \multicolumn{2}{|c|}{ Never } & \multicolumn{2}{|c|}{ Rarely } & \multicolumn{2}{|c|}{ Sometimes } & \multicolumn{2}{|c|}{ Often } & \multicolumn{2}{|c|}{ Always } \\
\hline & $\mathbf{F}$ & $\%$ & $\mathbf{F}$ & $\%$ & $\mathbf{F}$ & $\%$ & $\mathbf{F}$ & $\%$ & $\mathbf{F}$ & $\%$ \\
\hline $\begin{array}{l}\text { 24. I thoroughly revise the text to detect } \\
\text { relationships between thoughts. }\end{array}$ & 19 & 4,5 & 67 & 16 & 133 & 31,7 & 140 & 33,3 & 61 & 14,5 \\
\hline $\begin{array}{l}\text { 25. I check what I have previously } \\
\text { comprehended when I come across a } \\
\text { controversial information in the text. }\end{array}$ & 4 & 1 & 24 & 5,7 & 82 & 19,5 & 184 & 43,8 & 126 & 30 \\
\hline $\begin{array}{l}\text { 26. I try to guess what the text is about while } \\
\text { I read. }\end{array}$ & 8 & 1,9 & 23 & 5,5 & 82 & 19,5 & 188 & 44,8 & 119 & 28,3 \\
\hline $\begin{array}{l}\text { 27. I reread the text to increase } \\
\text { comprehension level when it seems hard } \\
\text { to comprehend. }\end{array}$ & 9 & 2,1 & 28 & 6,7 & 68 & 16,2 & 168 & 40 & 147 & 35 \\
\hline $\begin{array}{l}\text { 28. I ask myself questions I would like to } \\
\text { find answers to in the text. }\end{array}$ & 34 & 8,1 & 95 & 22,6 & 122 & 29 & 99 & 23,6 & 70 & 16,7 \\
\hline $\begin{array}{l}\text { 29. I check if my predictions about the text } \\
\text { are correct. }\end{array}$ & 10 & 2,4 & 60 & 14,3 & 125 & 29,8 & 153 & 36,4 & 72 & 17,1 \\
\hline $\begin{array}{l}\text { 30. I try to guess unknown words and } \\
\text { phrases in the text. }\end{array}$ & 13 & 3,1 & 47 & 11,2 & 133 & 31,7 & 150 & 35,7 & 77 & 18,3 \\
\hline $\begin{array}{l}\text { 31. I rephrase the entire text in my own } \\
\text { words. }\end{array}$ & 43 & 10,2 & 110 & 26,2 & 144 & 34,3 & 91 & 21,7 & 32 & 7,6 \\
\hline $\begin{array}{l}\text { 32. I adjust the pace of reading according to } \\
\text { the text. }\end{array}$ & 11 & 2,6 & 20 & 4,8 & 67 & 16 & 176 & 41,9 & 146 & 34,8 \\
\hline $\begin{array}{l}\text { 33. I discuss what I have read with others to } \\
\text { check if I have comprehended the text. }\end{array}$ & 34 & 8,1 & 72 & 17,1 & 133 & 31,7 & 119 & 28,3 & 62 & 14,8 \\
\hline
\end{tabular}

reading and rereading strategies had alignments with strategies used during reading concerning rereading and concentrating on hard parts. Moreover, the frequent use of comparing and guessing strategies indicated that students concentrated on some cognitive operations. As opposed to this, the lack of use regarding paraphrasing, questioning, and sharing strategies showed that students did not develop some critical thinking habits. For instance, teachers asking for summaries after book reading assignments as a proof that they have indeed read the book may have caused students to develop a negative perception towards summaries. Similarly, students may have put some distance to asking questions because some teachers and parents unfortunately dismiss questions directed to them. Therefore, students cannot reach the awareness that what they have read are materials to be shared due to the reasons that sharing reading-related comments are not covered in school activities, and people talking about the things they read are not favored in society.

Descriptive statistics regarding pre-service teachers' states of strategy use prior to, during, and after writing are presented below:

After examining the related Table 5, it was seen that the most frequently used strategies were designating a purpose (3), determining the audience (2), and using ways of idea generation (10) whereas the least frequent ones were using idea organizing techniques (7), choosing a suitable text structure (5), and determining main and supporting ideas (8). Frequent use of strategies focusing on designating purpose and determining the audience that are both crucial for writing is undoubtedly a positive occurrence. However, the weakness in collecting materials for the text will be a massive obstacle in the way of providing a proficient content. Similarly, Ülper (2011) found in his study that the $1^{\text {st }}, 6^{\text {th }}$, and $7^{\text {th }}$ strategies were used rarely while the $3^{\text {rd }}$ and $2^{\text {nd }}$ strategies were exploited frequently.

Considering what was reflected on the Table 6 , even though all four strategies were frequently used by students, it was revealed that revising the writing in terms of alignment with the purpose (13) strategy was used slightly more often than the others were used. Invariably, it was the same strategy dominating the other three in the research conducted by Ülper (2011). Following this strategy, strategies regarding content (11), spelling and punctuation (12), and editing in terms of suitability to text structure (14) were used. With regards to this, it can be concurred that the attention paid by students to designating a purpose continued on the level of editing.

When the Table 7 is taken into consideration, it can be seen that strategies indicating that students correct themselves $(15,16,17,18)$ are high in frequency while strategies implying peer correction $(19,20,21)$ are rarely used. Gathering similar results, Ülper (2011) reached the same conclusion. According to that, it can be argued that students regard writing as an individual task and suffer from writing anxiety. Furthermore, considering that sharing the writings with others was left in the past where good writing examples were displayed in pin boards in the class- 
Table 5. Descriptive statistics regarding the strategies prior to writing

\begin{tabular}{|c|c|c|c|c|c|c|c|c|c|c|}
\hline \multirow[t]{2}{*}{ Strategy } & \multicolumn{2}{|c|}{ Never } & \multicolumn{2}{|c|}{ Rarely } & \multicolumn{2}{|c|}{ Sometimes } & \multicolumn{2}{|c|}{ Often } & \multicolumn{2}{|c|}{ Always } \\
\hline & $\mathbf{F}$ & $\%$ & $\mathbf{F}$ & $\%$ & $\mathbf{F}$ & $\%$ & $\mathbf{F}$ & $\%$ & $\mathbf{F}$ & $\%$ \\
\hline $\begin{array}{l}\text { 1. I refresh my knowledge on the subject prior to writing } \\
\text { by discussing with my friends or scanning books. }\end{array}$ & 15 & 3,6 & 52 & 12,4 & 151 & 36 & 166 & 39,5 & 36 & 8,6 \\
\hline 2. I determine the audience prior to writing. & 8 & 1,9 & 29 & 6,9 & 59 & 14 & 194 & 46,2 & 130 & 31 \\
\hline $\begin{array}{l}\text { 3. I determine to what purpose my writing will serve } \\
\text { prior to writing. }\end{array}$ & 1 & 0.2 & 4 & 1 & 34 & 8,1 & 151 & 36 & 230 & 54,8 \\
\hline $\begin{array}{l}\text { 4. I limit the boundaries for the topic to serve my purpose } \\
\text { prior to writing. }\end{array}$ & 13 & 3,1 & 32 & 7,6 & 91 & 21,7 & 177 & 42,1 & 107 & 25,5 \\
\hline $\begin{array}{l}\text { 5. I choose an appropriate text structure to construct the } \\
\text { content prior to writing. }\end{array}$ & 8 & 1,9 & 47 & 11,2 & 108 & 25,7 & 171 & 40,7 & 86 & 20,5 \\
\hline $\begin{array}{l}\text { 6. I produce ideas by using techniques like brainstorming, } \\
\text { free writing, and listing prior to writing. }\end{array}$ & 17 & 4 & 46 & 11 & 95 & 22,6 & 148 & 35,2 & 114 & 27,1 \\
\hline $\begin{array}{l}\text { 7. I organize the ideas I have produced by using organizing } \\
\text { techniques like forming a topic tree, clustering, etc., } \\
\text { prior to writing. }\end{array}$ & 54 & 12,9 & 97 & 23,1 & 129 & 30,7 & 90 & 21,4 & 50 & 11,9 \\
\hline $\begin{array}{l}\text { 8. I specify main and supporting ideas, and organize } \\
\text { them as a text outline prior to writing. }\end{array}$ & 25 & 6 & 62 & 14,8 & 130 & 31 & 142 & 33,8 & 61 & 14,5 \\
\hline 9. I note down the ideas I have produced prior to writing. & 25 & 6 & 52 & 12,4 & 85 & 20,2 & 145 & 34,5 & 113 & 26,9 \\
\hline $\begin{array}{l}\text { 10. I use idea enhancing ways like exemplification, } \\
\text { elaboration, and providing evidence prior to writing. }\end{array}$ & 4 & 1 & 26 & 6,2 & 100 & 23,8 & 184 & 43,8 & 106 & 25,2 \\
\hline
\end{tabular}

Table 6. Descriptive statistics regarding the strategies during writing

\begin{tabular}{|c|c|c|c|c|c|c|c|c|c|c|}
\hline \multirow[t]{2}{*}{ Strategy } & \multicolumn{2}{|c|}{ Never } & \multicolumn{2}{|c|}{ Rarely } & \multicolumn{2}{|c|}{ Sometimes } & \multicolumn{2}{|c|}{ Often } & \multicolumn{2}{|c|}{ Always } \\
\hline & $\mathbf{F}$ & $\%$ & $\mathbf{F}$ & $\%$ & $\mathbf{F}$ & $\%$ & $\mathbf{F}$ & $\%$ & F & $\%$ \\
\hline $\begin{array}{l}\text { 11. I edit the text in terms of content by } \\
\text { revising what I have written during writing. }\end{array}$ & 4 & 1 & 13 & 3,1 & 44 & 10,5 & 149 & 35,5 & 210 & 50 \\
\hline $\begin{array}{l}\text { 12. I edit the text in terms of superficial (spelling } \\
\text { and punctuation) elements by revising what I } \\
\text { have written during writing. }\end{array}$ & 9 & 2,1 & 23 & 5,5 & 60 & 14,3 & 128 & 30,5 & 200 & 47,6 \\
\hline $\begin{array}{l}\text { 13. I revise the text in terms of appropriateness } \\
\text { to the purpose during writing. }\end{array}$ & 3 & 0,7 & 13 & 3,1 & 36 & 8,6 & 173 & 41,2 & 195 & 46,4 \\
\hline $\begin{array}{l}\text { 14. I revise the text in terms of appropriateness } \\
\text { to the text structure during writing. }\end{array}$ & 6 & 1,4 & 16 & 3,8 & 76 & 18,1 & 186 & 44,3 & 136 & 32,4 \\
\hline
\end{tabular}

Table 7. Descriptive statistics regarding the strategies after writing

\begin{tabular}{|c|c|c|c|c|c|c|c|c|c|c|}
\hline \multirow[t]{2}{*}{ Strategy } & \multicolumn{2}{|c|}{ Never } & \multicolumn{2}{|c|}{ Rarely } & \multicolumn{2}{|c|}{ Sometimes } & \multicolumn{2}{|c|}{ Often } & \multicolumn{2}{|c|}{ Always } \\
\hline & $\mathbf{F}$ & $\%$ & $\mathbf{F}$ & $\%$ & $\mathbf{F}$ & $\%$ & $\mathbf{F}$ & $\%$ & $\mathbf{F}$ & $\%$ \\
\hline 15. I evaluate the text in terms of content after writing. & 4 & 1 & 18 & 4,3 & 75 & 17,9 & 186 & 44,3 & 137 & 32,6 \\
\hline $\begin{array}{l}\text { 16. I evaluate and edit the text in terms of } \\
\text { superficial (spelling and punctuation) elements } \\
\text { after writing. }\end{array}$ & 11 & 2,6 & 35 & 8,3 & 58 & 13,8 & 128 & 30,5 & 188 & 44,8 \\
\hline $\begin{array}{l}\text { 17. I evaluate and edit the text in terms of suitability to } \\
\text { my purpose after writing. }\end{array}$ & 4 & 1 & 14 & 3,3 & 66 & 15,7 & 173 & 41,2 & 163 & 38,8 \\
\hline $\begin{array}{l}\text { 18. I evaluate and edit the text in terms of suitability to } \\
\text { text structure after writing. }\end{array}$ & 7 & 1,7 & 27 & 6,4 & 74 & 17,6 & 180 & 42,9 & 132 & 31,4 \\
\hline $\begin{array}{l}\text { 19. I ask my friend to read and criticize the text in } \\
\text { terms of content after writing. }\end{array}$ & 42 & 10 & 91 & 21,7 & 131 & 31,2 & 96 & 22,9 & 60 & 14,3 \\
\hline $\begin{array}{l}\text { 20. I ask my friend to read and criticize the text in } \\
\text { terms of superficial (spelling and punctuation) } \\
\text { elements after writing. }\end{array}$ & 62 & 14,8 & 123 & 29,3 & 112 & 26,7 & 75 & 17,9 & 48 & 11,4 \\
\hline $\begin{array}{l}\text { 21. I ask my friend to read and criticize the text in } \\
\text { terms of structure. }\end{array}$ & 54 & 12,9 & 109 & 26 & 109 & 26 & 97 & 23,1 & 51 & 12,1 \\
\hline
\end{tabular}


Table 8. T-test results regarding the frequency of using reading strategies in terms of gender

\begin{tabular}{|c|c|c|c|c|c|c|c|c|c|}
\hline & \multirow[t]{2}{*}{ Gender } & \multirow[t]{2}{*}{$\mathbf{N}$} & \multirow[t]{2}{*}{ Mean } & \multirow[t]{2}{*}{ Std. Deviation } & \multicolumn{2}{|c|}{ Levene's test } & \multirow[t]{2}{*}{ df } & \multirow[t]{2}{*}{$\mathbf{T}$} & \multirow[t]{2}{*}{$\mathbf{P}$} \\
\hline & & & & & $\mathbf{F}$ & Sig & & & \\
\hline \multirow[t]{2}{*}{ General } & Female & 299 & 3,6240 & ,48443 & 3,110 & 079 & 418 & 3,16 &, $002 *$ \\
\hline & Male & 121 & 3,4488 & ,58295 & & & & & \\
\hline \multirow{2}{*}{$\begin{array}{l}\text { Prior to } \\
\text { Reading }\end{array}$} & Female & 299 & 3,7811 & 63759 & 4,044 &, 045 & 418 & 2,72 &, 007 \\
\hline & Male & 121 & 3,5914 & ,66685 & & & & & \\
\hline \multirow{2}{*}{$\begin{array}{l}\text { During } \\
\text { Reading }\end{array}$} & Female & 299 & 3,5301 & ,54870 & 613 & ,434 & 418 & 2,81 & ,005 \\
\hline & Male & 121 & 3,3589 & 60458 & & & & & \\
\hline \multirow{2}{*}{$\begin{array}{l}\text { After } \\
\text { Reading }\end{array}$} & Female & 299 & 3,6140 & ,55960 & 4,572 & ,033 & 418 & 2,42 & ,016 \\
\hline & Male & 121 & 3,4463 & 67392 & & & & & \\
\hline
\end{tabular}

$* \mathrm{p}<.05$

Table 9. T-test results regarding the frequency of using writing strategies in terms of gender

\begin{tabular}{|c|c|c|c|c|c|c|c|c|c|}
\hline & \multirow[t]{2}{*}{ Gender } & \multirow[t]{2}{*}{$\mathbf{N}$} & \multirow[t]{2}{*}{ Mean } & \multirow[t]{2}{*}{ Std. Deviation } & \multicolumn{2}{|c|}{ Levene's test } & \multirow[t]{2}{*}{ Df } & \multirow[t]{2}{*}{$\mathbf{T}$} & \multirow[t]{2}{*}{$\mathbf{P}$} \\
\hline & & & & & $\mathbf{F}$ & Sig & & & \\
\hline \multirow[t]{2}{*}{ General } & Female & 299 & 3,8371 & ,48962 & 3,556 & ,060 & 418 & 5,73 & ,000* \\
\hline & Male & 121 & 3,5148 & ,59452 & & & & & \\
\hline \multirow{2}{*}{$\begin{array}{l}\text { Prior to } \\
\text { Reading }\end{array}$} & Female & 299 & 3,7381 & ,55213 & ,412 &, 521 & 418 & 3,42 &, $001 *$ \\
\hline & Male & 121 & 3,5289 & 59978 & & & & & \\
\hline \multirow{2}{*}{$\begin{array}{l}\text { During } \\
\text { Reading }\end{array}$} & Female & 299 & 4,3010 & ,58765 & 7,902 &, 005 & 418 & 5,27 &, $000^{*}$ \\
\hline & Male & 121 & 3,9360 & ,76002 & & & & & \\
\hline \multirow{2}{*}{$\begin{array}{l}\text { After } \\
\text { Reading }\end{array}$} & Female & 299 & 3,7133 & 66400 & 6,859 & ,009 & 418 & 6,05 &, $000^{*}$ \\
\hline & Male & 121 & 3,2538 & ,79422 & & & & & \\
\hline
\end{tabular}

${ }^{*} \mathrm{p}<.05$

room and that students cannot find neither the opportunity nor the time to interact with others, it can be stated that thought of sharing their work with peers is non-existent with the students.

Results of t-test and descriptive statistics to answer the question "Is there any difference between pre-service teachers' use of strategies prior to, during, and after reading and their overall use of reading strategies in terms of genders?" are presented in Table 8.

The table presents the distribution of students' reading strategy use frequency levels in terms of genders and determines if there is a difference between them. According to the data, the total scores generated were 3,62 for females and 3,44 for males. Based on the t-test results in the table, there was a significant difference between genders in favor of females $\left[\mathrm{t}_{(418)}=3.16 ; \mathrm{p}<.05\right]$. Thus, it can be inferred that females used reading strategies more frequently than males did. When prior to reading, during reading, and after reading strategies were examined independently, it can be seen that females used strategies in higher frequencies than male students. These results showed similarities to the general situations. In addition, resembling results were found by Green and Oxford (1995), Sheorey and Mokhtari (2002), Güngör (2005), Sim (2007), Topuzkanamış (2009), Logan and Johnston (2010), Bektaş, Esen and Yiğit (2013), and Emre and Temur (2016). However, as a differing result, Karatay (2007) found that males were on a better level than female students in terms of using reading strategies.
Table 10. Anova test results of participants' frequency of reading strategy use in terms of department

\begin{tabular}{lccccc}
\hline & $\begin{array}{c}\text { Sum of } \\
\text { squares }\end{array}$ & df & $\begin{array}{c}\text { Mean } \\
\text { square }\end{array}$ & F & Sig. \\
\hline Between Groups & 3,693 & 10 &, 369 & 1,377 &, 188 \\
Within Groups & 109,663 & 409 &, 268 & & \\
Total & 113,356 & 419 & & & \\
\hline
\end{tabular}

T-test results and descriptive statistics to provide an answer to the question "Is there any difference between pre-service teachers' use of strategies prior to, during, and after writing and their overall use of writing strategies in terms of genders?" are presented in Table 9.

In the table, the distribution of students' writing strategy uses frequency levels in terms of genders and the determination if there is a difference between them are provided in the light of statistical data. While total general score of females were calculated as 3.83 , the males scored 3.51. According to t-test results, the difference between genders was on the favor of females and it was significant $\left.\mathrm{t}_{(418)}=3.55 ; \mathrm{p}<.05\right]$. With this regard, it can be deduced that females used the strategies more frequently than males did. When the processes were inspected separately as prior to writing, during writing, and after writing, it was indicated that females used strategies more often than males. Similar results were obtained by Bektaş Esen and Yiğit (2013). 
Table 11. Distribution of departments regarding participants' frequency of use in terms of reading strategies

\begin{tabular}{lccccc}
\hline Department & N & Mean & Std. Deviation & Minimum & Maximum \\
\hline Turkish & 52 & 3,6055 &, 47390 & 2,33 & 4,64 \\
Pre-school & 89 & 3,6347 &, 62654 & 1,00 & 5,82 \\
Computer and Instructional Technologies & 11 & 3,4628 &, 43810 & 2,73 & 4,15 \\
Primary School & 58 & 3,4049 &, 46012 & 2,30 & 4,27 \\
Social Sciences & 32 & 3,6922 &, 54115 & 2,39 & 4,52 \\
Mathematics & 50 & 3,6079 &, 46687 & 2,70 & 4,67 \\
Turkish Language and Literature & 20 & 3,7227 &, 58374 & 2,48 & 4,58 \\
Guidance and Counseling & 57 & 3,4965 &, 47042 & 2,21 & 4,88 \\
Physics & 8 & 3,7008 &, 50924 & 3,12 & 2,88 \\
Biology & 19 & 3,5885 &, 37920 & & 4,61 \\
Music & 24 & 3,5101 &, 53769 & 2,55 & 4,45 \\
Total & 420 & 3,5735 &, 52013 & & 4,52 \\
\hline
\end{tabular}

To answer the question "Does pre-service teachers' frequency of use in reading strategies differ in terms of department?", Anova results and descriptive statistics are provided in Table 10.

As presented in the table, considering the difference between departments in terms of frequency of writing strategy use, there was no significant difference among groups according to Anova results. At first glimpse, a difference was assumed -e.g. between Turkish teaching or language and literature and students of other departments, these results are considered natural considering that all students started university after graduation from high schools with similar educational experiences.

The Table 11 presents the distribution of frequency scores regarding reading strategies in terms of departments. According to the data, frequency of 3,57 indicates that students use reading strategies quite often. Moreover, department with the highest score $(3,72)$ was calculated to be the students from Turkish Language and Literature Education department. In a respective order, following departments were Physics $(3,70)$, Social Sciences $(3,69)$, Pre-School $(3,63)$, Mathematics $(3,60)$, Turkish $(3,60)$, Biology $(3,60)$, Music $(3,51)$, Guidance and Counselling $(3,49)$, Computer and Instructional Technologies $(3,46)$, and Primary School Education (40). Similar results were generated in a previous study (Topuzkanamış, 2009).

Anova results and descriptive statistics regarding the question "Does pre-service teachers' frequency of use in writing strategies differ in terms of department?" are presented in Table 12.

In the table on which Anova results regarding the departmental differences in the use of writing strategies, a statistically significant difference was calculated among groups. However, based on Scheffe test to determine which groups had significant difference, no such difference was detected. In relation to this, it can be interpreted that groups were equivalent in terms of their frequency of use regarding the writing strategies. This result has similarities to the findings generated by reading strategies.
Table 12. Anova test results of participants' frequency of writing strategy use in terms of department

\begin{tabular}{lccccc}
\hline & $\begin{array}{c}\text { Sum of } \\
\text { squares }\end{array}$ & df & $\begin{array}{c}\text { Mean } \\
\text { square }\end{array}$ & F & Sig. \\
\hline Between Groups & 6,388 & 10 &, 639 & 2,244 &, 015 \\
Within Groups & 116,415 & 409 &, 285 & & \\
Total & 122,803 & 419 & & & \\
\hline
\end{tabular}

Therefore, it can be argued that students started their university education with equivalent experiences in terms of writing experience.

The Table 13 sheds light onto the distribution of scores regarding students' use frequency of writing strategies in terms of departments. According to the general frequency score of 3,74 indicated by the data, students are assumed to use writing strategies quite frequently. In addition to that, students from Turkish Language Education department had the highest mean score $(3,91)$. Following the score of Turkish Education students, in a respective order, came Pre-school $(3,81)$, Turkish Language and Literature $(3,79)$, Social Sciences $(3,78)$, Primary School Education (3,75), Mathematics (3,74), Physics (3.71), Guidance and Counselling $(3,67)$, Computer and Instructional Technologies $(3,64)$, Biology $(3,54)$, and Music Education $(3,38)$

The Table 14 provides insight on the correlation between the students' levels of use regarding reading and writing strategies. Based on the data, a significant positive $(p<.05)$ and moderate (.526) correlation (Şencan, 2005) was calculated between two scores. The notion that there is an interaction between reading and writing skills is a fundamental acknowledgment (Göğüş, 1978; Baymur, 1946; Yang \& Plakans, 2012; Cheong, Zhu \& Liao, 2018). Moreover, there are exemplary studies revealing that reading affects writing. With this regard, Graham et al. (2018) concluded in their meta-analysis study that the reading instruction improves basic and high-level writing skills according to these studies. The moderate level correlation between two scores should 
Table 13. Distribution of departments regarding participants' frequency of use in terms of writing strategies

\begin{tabular}{|c|c|c|c|c|c|}
\hline Department & $\mathbf{N}$ & Mean & Std. Deviation & Minimum & Maximum \\
\hline Turkish & 52 & 3,9130 & ,48523 & 2,67 & 4,86 \\
\hline Pre-school & 89 & 3,8170 & ,49377 & 2,62 & 4,95 \\
\hline Computer and Instructional Technologies & 11 & 3,6407 &, 71504 & 2,24 & 4,57 \\
\hline Primary School & 58 & 3,7504 & ,45143 & 2,76 & 4,62 \\
\hline Social Sciences & 32 & 3,7857 &, 57283 & 2,29 & 4,76 \\
\hline Mathematics & 50 & 3,7448 & ,48684 & 2,52 & 4,57 \\
\hline Turkish Language and Literature & 20 & 3,7905 & ,61671 & 2,38 & 4,62 \\
\hline Guidance and Counseling & 57 & 3,6742 & ,49058 & 2,57 & 4,67 \\
\hline Physics & 8 & 3,7143 & ,38686 & 3,19 & 4,33 \\
\hline Biology & 19 & 3,5439 & ,67087 & 1,29 & 4,71 \\
\hline Music & 24 & 3,3810 & ,79632 & 1,00 & 4,29 \\
\hline Total & 420 & 3,7442 & ,54137 & 1,00 & 4,95 \\
\hline
\end{tabular}

Table 14. Anova test results of participants' frequency of writing strategy use in terms of department

\begin{tabular}{lccccc}
\hline & N & Mean & $\begin{array}{c}\text { Std. } \\
\text { Deviation }\end{array}$ & P & r \\
\hline Reading & 420 & 3,5735 &, 52013 &, 000 &, 526 \\
Writing & 420 & 3,7442 &, 54137 & & \\
\hline
\end{tabular}

be interpreted as a reflection of the interaction between reading and writing skills.

\section{FINDINGS AND INTERPRETATION}

The research reached the conclusion that pre-service teachers use reading and writing strategies quite frequently. Considering the studies conducted on similar samples in the context of reading strategies, Kuş and Türkyılmaz (2010) found the levels to be low while moderate levels were detected by Karatay (2007) and Topuzkanamış (2009); in addition, Çöğmen (2008) revealed high-level reading strategies from the sample. In the sense of writing strategies, on the other hand, Ülper (2011) deduced similar findings. Even though the results of the research produced positive outcomes on surface level, students' reading and writing achievements can be taken into consideration as the products of their own views on their self-efficacy since their interests and habits were not measured.

The reason for this is that it is hard to claim any type of success reflecting students' strategy use rates in the sense of reading and writing skills. Thus, the use of research method named by Cohen (1987) as thinking aloud can provide a more detailed and to-the-depth information and observation opportunities.

The research revealed that use frequencies of reading and writing strategies did not differ in terms of departments, yet it showed differences with regards to gender. Although the equivalence between use frequencies of reading and writing strategies in terms of departments appeared as a surprising outcome, this indicates that students of the faculty of education had similar experiences in their primary, secondary, and high school educations, graduating with virtually equivalent reading and writing experiences. On the other hand, even though students get separated into different fields such as social studies, science, foreign language, etc. in high schools, these fields focusing solely on exam success neglect developing these skills on both teacher and student levels. The differentiation on the matter can be predicted to occur during the second, third, and fourth years of the faculty education because departments similar to Turkish Language Teaching and Turkish Language and Literature are expected to offer their students reading and writing experiences more than other departments do. Gender-related results of the research coincides with findings of other similar studies (Sim, 2007; Karatay, 2007; Topuzkanamış, 2009) concluding that female students indicate a higher success level than male students in terms of using strategies. One of the reasons for this occurrence might be that females have more motivation towards learning and reading on the ground that they have no alternative ways to start earning money other than education and that male students indicating a low motivation towards learning and reading have the opposite inclinations. To support this, it can be inferred from the number of participants in the research that females, as a product of the same mindset, preferred faculties of education more than males did.

The research revealed a moderate correlation between the scores of frequencies of reading and writing strategies. Indeed, the relationship between reading and writing is a notion that has been mentioned for the last decades. In connection, related research indicates the existence of certain areas used for both skills. For instance, Fitzgerald and Shanahan (2000) categorize them as follows: meta-knowledge, domain-knowledge, knowledge about universal text attributes, and procedural knowledge. Moreover, researchers such as Sahanahan and Lomax (1986), Abbott and Berninger (1993), Juel et al. (1986) and Allen et al. (2014) conducted studies that indicated the common grounds between reading and writing achievements. However, the connection between reading and writing strategies has not 
been investigated frequently. According to this limited research (Shanahan, 1984; Ryan, 1985; Kirby, 1986; Langer, 1986), in some strategies, both skills are jointly employed. Even though current studies have mentioned a commonality between two skills, it is explicit that this cooperation is not an overlapping. Therefore, this finding and the finding indicating no high correlation between reading and writing strategies match each other. Yet, an individual using reading strategies frequently does not suggest a good writing just as a frequent user of writing strategies does not imply a quality reading comprehension. At this point, it can be deduced that the success in reading and writing comes with the individual's use of meta-strategies.

\section{REFERENCES}

Abbott, R., \& Berninger, V. W. (1993). Structural equation modeling of relationships among developmental skills and writing skills in primary- and intermediategrade writers. Journal of Educational Psychology, 85, 478-508.

Allen, L. K., Snow, E. L., Crossley, S. A., Jackson, G. T., \& McNamara, D. S. (2014). Reading comprehension components and their relation to writing. LAnnee psychologique, 114(4), 663-691 https:/www.cairn.info/revue-1-annee-psychologique1-2014-4-page-663.htm.

Baymur, F. (1946). Türkçe ögretimi Birinci Kitap, Kenan Matbaas1, İstanbul.

Bektaş Esen, E. ve Yiğit, N. (2013). Öğrencilerin fen ve teknoloji dersinde kullandıkları okuma ve yazma stratejileri, Fen Eğitimi ve Araştırmaları Derneği Fen Bilimleri Öğretimi Dergisi, Volume: 1 Issue: 1.

Brand-Gruwel, S., Aarnoutse, C. A. J., \& van den Bos, K. P. (1998). Improving text comprehension strategies in reading and listening settings. Learning and Instruction, 8(1), 63-81. http://dx.doi.org/10.1016/ S0959-4752(97)00002-9.

Burles, Faye Dinah. (2000). Use of Metacognitive Strategies When Reading Both Narrative and Expository Text. Unpublished master's thesis. University of Victoria Faculty of Education, Canada.

Cain, K. (1999). Ways of reading: How knowledge and use of strategies are related to reading comprehension. British Journal of Developmental Psychology, 17(2), 293 309. http://dx.doi.org/10.1348/026151099165285.

Casbarro, Susan Nanna. (1996). Content area reading strategies for English speakers of other languages (CARS for ESOL). Unpublished master's thesis. Nova Southeastern University

Cheong, C. M., Zhu, X., \& Liao, X. (2018). Differences between the relationship of L1 learners' performance in integrated writing with both independent listening and independent reading cognitive skills. Reading and Writing, 31(4), 779-811.

Clouse, B. F. (2002). Transitions: From reading to writing. WCB/McGraw-Hill.

Çöğmen, S. (2008). Eğitim fakültesi öğrencilerinin kullandığı okuduğunu anlama stratejileri, Yayımlanmamış
Yüksek Lisans Tezi, Adnan Menderes Üniversitesi, Aydin.

De La Paz, S., and Graham, S. (2002). Explicitly teaching strategies, skills, and knowledge: Writing instruction in middle school classrooms. Journal of Educational Psychology, 94(4), 687-698.

Emre, Y., \& Temur, T. (2016). Farklı akademik seviyedeki ilkokul 4. sınıf öğrencilerinin okuma stratejilerini kullanma durumları. Electronic Turkish Studies, 11(3), 2571-2598.

Firat, M., \& Kurt, A. (2015). İnternette bilgi kirliliği ölçeğinin geliştirilmesi ve uygulanmasi. Eğitimde Kuram ve Uygulama, 11(1), 89-103.

Fitzgerald, J., \& Shanahan, T. (2000). Reading and writing relations and their development. Educational Psychologist, 35, 39-50 https://doi.org/10.1207/ S15326985EP3501 5.

Gelen, İsmail. (2003). Bilişsel farkindalik stratejilerinin türkçe dersine ilişkin tutum, okuduğunu anlama ve kaliciliğa etkisi. Unpublished Doctoral Thesis. Çukurova Üniversitesi, Adana.

Göğüş, B. (1978). Orta dereceli okullarımızda Türkçe ve yazın eğitimi. Ankara: Kadığlu Matbaası.

Grabe, W. (2003). Reading and writing relations: second language perspectives on research and practice. In B. Kroll (ed.), Exploring the dynamics of second language writing. Cambridge: Cambridge University Press, 241-262.

Graham, S., Kiuhara, S. A., Harris, K., \& Fishman, E. J. (2017). The relationship among strategic writing behavior, writing motivation, and writing performance with young, developing writers. Elementary School Journal, 118(1), 82-104. https://doi.org/10.1086/693009

Graham, S., Liu, X., Bartlett, B., Ng, C., Harris, K. R., Aitken, A., Barkel, A, Kavanaugh, C., \& Talukdar, J. (2018). reading for writing: a meta-analysis of the impact of reading interventions on writing. Review of Educational Research, 88(2), 243-284.

Green, J. M., \& Oxford, R. (1995). A closer look at learning strategies, L2 proficiency, and gender. TESOL quarterly, 29(2), 261-297.

Güngör, Arzu. (2005). Altınc1, yedinci ve sekizinci sınıf öğrencilerinin okuduğunu anlama stratejilerini kullanma düzeyleri. Hacettepe Üniversitesi Ë̆itim Fakültesi Dergisi. S. 28, s. 101-108.

Hinduja, S., \& Patchin, J. W. (2007). Offline consequences of online victimization: School violence and delinquency. Journal of school violence, 6(3), 89-112.

Hopkins, C. (2002). Improving tenth-grade students' five paragraph essay writing skills using various writing strategies, guided assignments, and portfolios for growth. M.A. Action Research Project, Nova Southeastern University.

İnal, S. (2006). Yabancl dil öğretimindeki hedeflerin gerçekleştirilmesinde (clustering) yazılı anlatım tekniğ $i$ nin ögrenci tutumu ve başarısı üzerindeki etkileri (Doctoral dissertation, DEÜ).

Juel, C., Griffith, P., \& Gough, P. (1986). A longitudinal study of the changing relationships of word recognition, 
spelling, reading comprehension, and writing from first to second grade. Journal of Educational, 78, 243-255.

Kaplan, A. M., \& Haenlein, M. (2010). Users of the world, unite! The challenges and opportunities of social media. Business horizons, 53(1), 59-68.

Karatay, Halit. (2007). Illköğretim Türkçe ögretmeni adaylarının okuduğunu anlama becerileri üzerine alan araştırması. Unpublished Doctoral Thesis. Gazi University, Ankara.

Kirby, K. (1986). Reading and writing processes of selected high-risk college freshmen. Unpublished doctoral dissertation, University of Georgia.

Kumar, A. (2013). Rise in polluters of scientific research: How to curtail information pollution (infollution). Journal of Natural Science, Biology and Medicine, 4(2), 271-271.

Langer, J. A. (1986). Children reading and writing: Structures and strategies. Norwood, NJ: Ablex.

Logan, S., \& Johnston, R. (2010). Investigating gender differences in reading. Educational Review, 62(2), $175-187$.

MEB. (2015) Uluslararası Öğrenci Değerlendirme Programı PISA 2015 Ulusal Raporu. Retrieved 11.6.2019. http://pisa.meb.gov.tr/wp-content/uploads/2014/11/ PISA2015_UlusalRapor.pdf

Monroe, B. W. \& Troia, G. A. (2006). "Teaching Writing Strategies to Middle School Students with Disabilities". The Journal of Educational Research, vol. 100, 1. pp. 21-33.

Muijselaar, M. M., \& de Jong, P. F. (2015). The effects of updating ability and knowledge of reading strategies on reading comprehension. Learning and Individual Differences, 43, 111-117. http://dx.doi.org/10.1016/j.lindif.2015.08.011

National Assessment of Educational Progress. (2009). The Nation's Report Card: Reading 2009. Retrieved 11.6.2019, nces.ed.gov/nationsreportcard/reading.

National Assessment of Educational Progress. (2011). The Nation's Report Card: Writing 2011. Retrieved 11.6.2019, nces.ed.gov/nationsreportcard/writing.

National Research Council. 1998. Preventing Reading Difficulties in Young Children. Washington, DC: The National Academies Press. https://doi.org/10.17226/6023.

O'Keeffe, G. S., \& Clarke-Pearson, K. (2011). Clinical report - the impact of social media on children, adolescents, and families. Pediatrics, peds-2011. www.pediatrics.org/cgi/doi/10.1542/peds.2011-0054 doi:10.1542/ peds.2011-0054

Özdemir, Ş. (2016). Individual contributions to infollution (information pollution): trust and share. International Journal on New Trends in Education and Their Implications, 7(2), 23-33.

Ryan, S. M. (1985). An examination of reading and writing strategies of selected fifth grade students. In J. Niles \& R. Lalik (Eds.), Issues in literacy: A research perspective (Thirty-fourth yearbook of the National Reading Conference, pp. 386-390), Rochester, NY: National ReadingConference.
Şen, H. Ş. (2003). Biliş ötesi stratejilerin ilköğretim okulu beşinci sınıf ögrencilerin okuduğunu anlama düzeylerine etkisi. Unpublished Doctoral Thesis. Gazi University, Ankara.

Şencan, H. (2005). Sosyal ve davranışsal ölçümlerde güvenilirlik ve geçerlilik. Ankara: Seçkin Yayıncılık.

Shanahan, T. (1984). Nature of the readingwriting relation: An exploratory multivariate analysis. Journal of Educational Psychology, 76, 466-477.

Shanahan, T., \& Lomax, R. G. (1986). An analysis and comparison of theoretical models of the reading-writing relationship. Journal of Educational Psychology, $78(2),-116$.

Shen, M. Y. (2009). Reading-writing connection for EFL college learners' literacy development. The Asian EFL Journal, 11(1), 89-108.

Sheorey, R., \& Mokhtari, K. (2001). Differences in the metacognitive awareness of reading strategies among native and non-native readers. System, 29(4), 431-449.

Solmaz, B., Tekin, G., Herzem, Z., \& Demir, M. (2013). İnternet ve Sosyal Medya Kullanimi Üzerine Bir Uygulama. Selçuk üniversitesi iletişim fakültesi akademik dergisi, 7(4), 23-32.

Spörer, N., Brunstein, J. C., \& Kieschke, U. (2009). Improving students' reading comprehension skills: effects of strategy instruction and reciprocal teaching. Learning and Instruction, 19(3), 272-286. http://dx.doi. org/10.1016/j.learninstruc.2008.05.003

Temizkan, Mehmet. (2007). İlköğretim ikinci kademe Türkçe derslerinde okuma stratejilerinin okuduğunu anlama üzerindeki etkisi. Unpublished Doctoral Thesis. Gazi University, Ankara.

Tierney, R. J., \& Pearson, P. D. (1983). Toward a composing model of reading. Language arts, 60(5), 568-580.

Tierney, R. J., Soter, A., O’Flahavan, J. F., \& McGinley, W. (1989). The effects of reading and writing upon thinking critically. Reading Research Quarterly, 134-173.

Topuzkanamış, E. (2009). Öğretmen adaylarının okuduğunu anlama ve okuma stratejilerini kullanma düzeyleri. Unpublished Master's Thesis. Balıkesir University, Balikesir.

Ülper, H. (2008). Bilişsel süreç modeline göre hazırlanan yazma öğretimi programının öğrenci başarısına etkisi. Unpublished Doctoral Thesis, Ankara University, Ankara.

Ülper, H. (2011). Öğretmen adaylarının yazma stratejilerini kullanma ve bu stratejilere dönük eğitim alma durumlarına ilişkin bir inceleme. G. L. Uzun ve Ü. Bozkurt. (Ed.). Türkçenin Eğitimi-Öğretiminde Kuramsal ve Uygulamalı Araştırmalar. Essen: Die Blaue Eule, ss. 209-223.

Vural, Z., \& Bat, M. (2010). Yeni bir iletişim ortamı olarak sosyal medya: Ege Üniversitesi İletişim Fakültesine yönelik bir araştırma. Journal of Yasar University, 5(20).

Yang, H. C., \& Plakans, L. (2012). Second language writers' strategy use and performance on an integrated reading-listening-writing task. TESOL Quarterly, 46(1), 80-103. 
Yazar, Ulvican. (2001). Teaching reading effectively with reading strategies. Unpublished Master's Thesis. Atatürk University, Erzurum.
Zsigmond, I. (2015). Writing strategies for fostering reading comprehension. Procedia-Social and Behavioral Sciences, 180, 1698-1703. 